\section{Korleis føreseie risikoen for iskemisk hjartesjukdom?}

\author{
Ved å bruke dei mest informative mål for overvekt, hypertensjon \\ og serum-lipidnivå kan ein betre berekne pasientens risiko for iskemisk \\ hjartesjukdom.
}

Hypertensjon, overvekt og høge blodlipidnivå er kjende risikofaktorar for iskemisk hjartesjukdom, men det er ikkje klårt korleis dei påverkar einannan og kva mål som i høgst grad føreseiar framtidig risiko. Bjørn Mørkedal har jamført data frå Dødsårsaksregisteret med data om 60000 personar i HUNTundersøkinga for å finne svar på dette.

- Vi fann at samanhengen mellom blodtrykk og død av hjartesjukdom var mykje sterkare hjå dei under 65 år enn hjå dei over. Denne samanhengen var også sterkare for dei tynne og normalvektige enn for dei overvektige og tjukke, seier Mørkedal.

- Vi fann vidare at hjå menn er det sterkast samanheng mellom systolisk blodtrykk og hjartesjukdom, medan det hjå kvinner er sterkast samanheng med pulstrykket. For overvekt er forholdstalet mellom midje- og hoftemål justert for kroppsmasseindeks, og for serum-lipidnivå er forholdstalet mellom total- og HDL-kolesterolnivå mest informativt når det gjeld død av hjartesjukdom hjå både menn og kvinner.

Mørkedal har også sett på samanhengen mellom jernnivå $\mathrm{i}$ blodet og risiko for iskemisk hjartesjukdom og fann at risikoen auka ved lågt jernnivå.

\section{Kristin Viste}

kristin.viste@legeforeningen.no

Tidsskriftet

\section{Ordforklaring}

Helseundersøkinga i Nord-Trøndelag (HUNT) omfattar alle innbyggjarar over 20 år i fylket.

Det er samla inn data via spørjeundersøkingar. kliniske undersøkingar og prøvar frå blod, urin og vev.

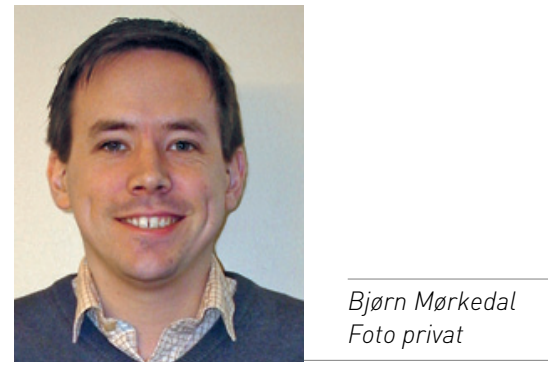

Disputas

Bjørn Mørkedal disputerte for ph.d.-graden ved Norges teknisk-naturvitenskapelige universitet 13.1. 2012. Tittelen på avhandlinga hans er Blood pressure, obesity, serum iron and lipids as risk factors of ischaemic heart disease.

\title{
Hvorfor tar ikke pasienten medisinene?
}

\author{
Hos personer med schizofreni eller bipolar lidelse er dårlig sykdomsinn- \\ sikt, negativ holdning til medisinering og alkohol- eller narkotikabruk \\ viktigere årsaker enn bivirkninger av medisinen.
}

Medikamenter er en viktig del av behandlingsopplegget for personer med schizofreni eller bipolare lidelser, og har betydning for prognose og utfall av sykdommen.

- Hvis pasienten tar medisinene som foreskrevet, kan de bli spart for lidelse. Likevel har legen ofte problemer med å motivere pasienten til å ta medisin. Det er viktig å motivere pasientene til å gjøre det. For å kunne motivere må vi forstå årsaken til at mange ikke følger de medisinske anbefalingene, sier Halldóra Jónsdóttir.

Hun har undersøkt om 280 personer med schizofreni eller bipolare lidelser følger den medikamentelle behandlingen de er anbefalt, blant annet ved å måle medikamentnivå $\mathrm{i}$ blodet. Hun har også benyttet intervjuer og spørreskjemaer for å finne hva som er årsaken til at mange ikke følger anbefalt medisinering.

- Våre undersøkelser viser at dårlig sykdomsinnsikt, negative holdninger til medi- kamenter og alkohol- eller narkotikabruk ofte fører til at pasienter ikke følger anbefalt medisinering - dette må regnes som risikofaktorer for dårlig etterlevelse. Bivirkninger av medikamentene, som kvalme og diaré, kan også være risikofaktorer. Redusert kognitiv funksjon ser ut til å ha mindre betydning, sier Jónsdóttir.

De som ikke tok medisinene sine, mente ofte at det var unødvendig og var også mer bekymret for medisineringen enn de som fulgte behandlingsopplegget. Polikliniske pasienter med alvorlige psykiske lidelser fulgte i stor grad anbefalt medisinering, men også her var negative holdninger til medikamenter og alkohol- eller narkotikabruk knyttet til dårlig etterlevelse.

\section{Anne Forus}

anneforus@hotmail.com

Tidsskriftet

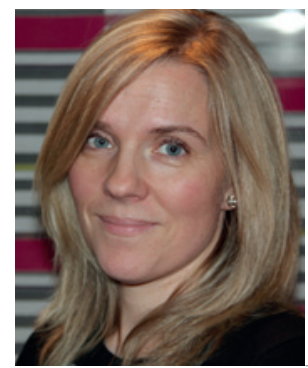

Halldóra Jónsdóttir. Foto privat

\section{Disputas}

Halldóra Jónsdóttir disputerte for ph.d.-graden ved Universitetet i Oslo 3.2. 2012. Tittel på avhandlingen er Adherence to pharmacological treatment in patients with severe mental disorders. 